17

\title{
Decay Rates of Zoonotic Pathogens and Viral Surrogates in Soils Amended with Biosolids
} and Manures and Comparison of qPCR And Culture Derived Rates

(1) B.N. Roberts ${ }^{1}$, R.H. Bailey ${ }^{2}$, M.R. McLaughlin ${ }^{1}$, and J.P. Brooks ${ }^{1}$

(1)

7

${ }^{1}$ Agriculture Research Services, United States Department of Agriculture, Mississippi State, MS 39762

${ }^{2}$ Pathobiology and Population Medicine Department, College of Veterinary Medicine, Mississippi State University, Mississippi State, MS 39762

(1)

Key words: Campylobacter, Clostridium perfringens, E. coli O157:H7, land application, Listeria, MS2, ØX174, Salmonella, waste, manure, biosolids

Running title: Microbial decay in waste-amended soil

\section{Correspondence}

Brandy Roberts, Agriculture Research Services, United States Department of Agriculture, POB 5367, Mississippi State, MS 39762, USA. E-mail: bnh3@msstate.edu

Approved for publication as Journal Article No. J-XXXXX of the Mississippi Agricultural and Forestry Experiment Station, Mississippi State University. Mention of a trade name, proprietary product, or specific equipment does not constitute a guarantee or warranty by the USDA and does not imply its approval to the exclusion of other products that may be suitable. This work was prepared by employees of the U.S. Government as part of their official duties and is in the public domain and may be used without further permission. 
Aims: The purpose of this study was to establish inactivation constants of foodborne pathogens and coliphage in clay and sandy soils to be used in quantitative microbial risk analysis and compare cultural and qPCR methods in determining if inactivation rates differ among certain

32 bacteria.

Methods and Results: Salmonella enterica, Campylobacter jejuni, Listeria monocytogenes, Escherichia coli O157:H7, Clostridium perfringens, were seeded together with MS2 and ØX174 phages, into three waste matrices (Class B biosolids, swine lagoon effluent, cattle manure), and phosphate buffered saline (PBS) as a control, and applied to two soil types (sandy loam, clay

37 loam) using two application practices (incorporated, surface applied). S. enterica survived longer and at higher levels in cattle manure than in other matrices. Culturally, C. jejuni and $L$. monocytogenes were below detection limits $\left(\sim 200 \mathrm{CFU} \mathrm{g}^{-1}\right)$ by days 7 and 28 , respectively, but molecularly, both were detectable 28+ days. Clostridium perfringens persisted at higher levels

41 in biosolids and swine lagoon effluent, regardless of waste, soil type, or application practice.

42 Phage survival was longer for MS2 in biosolids than in other waste matrices, while $\varnothing \times 174$ did not differ; neither survived longer than 90 days.

44 Conclusions: Class B biosolids and cattle manure sustained pathogens longest. Higher solid 45 content waste-residual as opposed to liquid waste may provide suitable matrices capable of 46 protecting pathogens.

47 Significance and Impact of the Study: This study provides new and more conclusive decay rate data that will be useful for assessment of public and occupational health risks. 


\section{INTRODUCTION}

52 Quantitative microbial risk assessment (QMRA) defines potential individual and population

53 health risks associated with microbial pathogens. QMRA models rely on important inputs such

54 as pathogen levels, transport, decay rates, and dose response parameters (Brooks et al., 2012;

55 Haas et al., 1999). Fresh food crop outbreaks have often left more questions regarding pathogen

56 presence, transport, and inactivation once in the field (Brooks et al., 2012; Eileen R. Choffnes et

57 al., 2012). Fecal contamination of crops can occur naturally by wild and feral animals or by

58 insect movements from feces to food crops (Moore and Gross, 2010). Contamination can occur

59 unintentionally from accidental release of manure from animal feeding operations, or as an

60 unintended consequence following land application of biosolids or manure. Land application of

61 biosolids and manure poses a growing concern for environmental and human health risks due to

62 the zoonotic microbial pathogen loads found in these waste products and to the increasing

63 volumes of these waste residuals as the size and scope of animal feeding operations increases to

64 keep pace with worldwide food demand. Although much is known about potential threats from

65 foodborne microbial pathogens, knowledge gaps exist and must be filled to understand the

66 survival and fate of these pathogens when introduced into the environment.

67

Any untreated fecal waste potentially harbors pathogens (Gerba and Smith, 2005;

68 Hutchison et al., 2005). Common foodborne bacterial pathogens which can be isolated from

69 both human and animal wastes are Campylobacter jejuni, Salmonella enterica, Listeria

70 monocytogenes, Escherichia coli $\mathrm{O} 157: \mathrm{H} 7$ and Clostridium perfringens, all of which have been

71 implicated in foodborne outbreaks (Moore and Gross, 2010; Scallan et al., 2011). Additionally, 
72 viral pathogen loads can be extremely high in feces of infected hosts. Because viruses are often

73 host specific, the main environmental source for human enteric viral transmission is biosolids or

74 untreated sewage (USDA-NASS., 2011). Common viruses that are found in biosolids are

75 norovirus, adenovirus, enterovirus, hepatitis A and E, and rotavirus (USEPA, 1995; Viau et al.,

76 2011; Wong et al., 2010). Use of animal and human viruses in decay studies is limited by the

77 need for animal cell-culture models and by difficulty in virus propagation, hence the use of

78 surrogate phage models. MS2 phage is routinely used as an indicator of adenoviruses (USEPA,

79 1995), rotavirus (Bhattarai et al., 2011), norovirus (D'Souza and Su, 2010), and enteric viruses in

80 residual wastes (Katz and Margolin, 2007). The somatic DNA phage, ØX174, is a surrogate for

81 adenovirus (Berger et al., 2010) and an ideal contrast to MS2, which is a male specific, RNA

82 coliphage. In the present study, $\varnothing$ X174 and MS2 were used to estimate viral decay rates in

83 waste residuals applied to sandy loam and clay loam soils.

Pathogens may survive in the environment for days to months (Holley et al., 2006; Inglis

85

86

87

88

89

90

91

92

93

94

et al., 2010; Islam et al., 2004; Scallan et al., 2011; USEPA, 1995; You et al., 2006), but site- and waste-specific survival rates for these pathogens are not well defined. Several studies have reported decay rates for microbes associated with residuals applied to soils (Table 1) (Holley et al., 2006; Lang et al., 2007; Lang and Smith, 2007; Rogers et al., 2011; Straub et al., 1992; Toth et al., 2011), but most studies were limited to a single pathogen and soil type or multiple pathogens and a single waste residual. Thus far, no studies have compared microbial decay rates in biosolids and manure.

One aspect of QMRA that is not yet fully understood is the use of molecular data in current models. In low nutrient and high stress environments, many pathogens can enter a reduced metabolic state called "viable but non-culturable" (VBNC) (Freestone and Lyte, 2010; 
Hutchison et al., 2005; Olsen et al., 2000). When VBNC bacteria cannot be isolated using standard culture methods and enrichment processes, quantitative polymerase chain reaction (qPCR) can bypass this limitation and allow quantifiable pathogen-specific detection. Both culture and molecular analysis have benefits and limitation; a comparison of the detection of pathogens provides insight into whether the derived decay rates of foodborne pathogens are statistically different. Because of the inhibitory properties of humic acid in soil and the small quantities analyzed it has been concluded that culture analysis may be more sensitive in some samples (Colinon et al., 2013). The present study reports results of microcosm experiments which investigated multiple variables (waste residual type, soil type, pathogen, and residual management), to: 1) understand the effects of soil type, waste type, and residual management which influence microbial decay in waste-amended soils; and 2) compare cultivation-dependent and -independent (i.e. qPCR) methods of determining microbial decay rates.

\section{METHODS}

\subsection{Study Design}

The experimental design was laid out as factorial $(4 \times 2 \times 2 \times 2)$ with four residuals (Class B biosolids, cattle manure, swine lagoon effluent, and phosphate buffered saline [PBS] control) applied to two types of southeastern soils (Stough and Leeper), using two application management practices (surface-applied residual incorporated and not incorporated), with two pathogen levels (concentrated pathogen-spiked cocktail and sterile PBS). Pathogen-spiked cocktails comprised S. enterica, E. coli O157:H7, L monocytogenes, C. jejuni, C. perfringens, MS2, and ØX174. Treatments were replicated in triplicate and assayed at 11 time points $(0,7$, $14,21,28,60,90,120,150,180,210 \mathrm{~d})$. 
118 Soils were collected from the Mississippi State University R. R. Foil Plant Science Research

119 Center (North Farm). Stough (sandy loam) soil is taxonomically classified as coarse-loamy,

120 siliceous, semi-active, thermic Fragiaquic Paleudults, and Leeper (clay loam) soil as fine,

121 smectitic, nonacid, thermic Vertic Epiaquepts. Each soil was homogenized by passage through a

$122 \quad \# 10$ (2.54 cm) nominal sized sieve. Residual waste (swine effluent, cattle manure, and Class B

123 biosolids) were collected from local farms or municipalities. Swine effluent and cattle manure

124 were collected from a commercial pig rearing facility and local independent rancher,

125 respectively. Class B biosolids were collected from a regional municipal wastewater treatment

126 plant. Residual wastes were collected 2-3 days prior to study commencement. Moisture content

127 was assessed by weighing $10 \mathrm{~g}$ of soil, heating at $104^{\circ} \mathrm{C}$ for $48 \mathrm{~h}$, reweighing the soil, and

128 calculating the difference as \% moisture. Stough fine sandy loam consisted of $64 \%$ sand, $27 \%$

129 silt, $10 \%$ clay, and pH 5, and Leeper silty clay loam was 20\% sand, $49 \%$ silt, $31 \%$ clay, and pH 7

130 (Abdelwhab et al., 2011).

\subsection{Inoculant Preparation}

Salmonella enterica (ATCC 14028), E. coli O157:H7 (ATCC 43895), and Listeria monocytogenes (ATCC 51722) cells were prepared by growing each bacterial culture to

134 exponential phase (approximately $6 \mathrm{~h}$ ) in tryptic soy broth (TSB) in 50-mL centrifuge tubes at $13535^{\circ} \mathrm{C}$ with shaking at $200 \mathrm{rpm}$. Campylobacter jejuni (ATCC 33560) was prepared by growing 136 to exponential phase (approximately $24 \mathrm{~h}$ ) in Campylobacter Enrichment Broth (CEB) in 50-mL 137 centrifuge tubes at $42^{\circ} \mathrm{C}$ in microaerophilic conditions. Clostridium perfringens (ATCC 3624) 138 was inoculated in TSB and grown overnight at $44.5^{\circ} \mathrm{C}$, anaerobically, followed by inoculation 
139 into Duncan sporulation media (1:10 v:v) and sporulated at $35^{\circ} \mathrm{C}$ for 2 weeks. Each culture was

140 pelleted by centrifugation at $5000 \times \mathrm{g}$ for $30 \mathrm{~min}$. Supernatants were decanted, pellets were re-

141 suspended in an equal volume of sterile PBS, and the process was repeated for a total of three

142 times. Final washed cells were suspended in $25 \mathrm{~mL}$ PBS for titer determinations $\left(10^{8}\right.$ to $10^{9} \mathrm{~mL}^{-}$

$143^{1}$ ) and storage at $4^{\circ} \mathrm{C}$. All cells were used within 3-7 days of preparation and were quantified

144 prior to inoculation into wastes.

\section{$145 \quad 2.4$ Bacteriophage Preparation}

146 MS2 (ATCC 15597-B1) and ØX174 (ATCC 13706-p1) coliphages were propagated in E. coli

147 (ATCC 15597) and E. coli (ATCC 13706), respectively, to $10^{6}$ plaque forming units (PFU) $\mathrm{mL}^{-1}$ 148 according to (Brooks et al., 2005).

\subsection{Soil Microcosms}

Dry soil (150 g per microcosm) was placed in 355-mL Styrofoam cups. Waste residuals were

151 applied at a rate of $10 \%$ based on the dry weight of soil (15 $\mathrm{g}$ or $\mathrm{mL}$ depending on the waste

152 matrix), to mimic the top soil surface layer $(0-10 \mathrm{~cm})$ following a land application event. Prior

153 to waste application, each of the three wastes and PBS was seeded with bacteria and phages to

154 final levels of approximately $10^{6} \mathrm{~g}^{-1}$ of soil for each microbe. For comparison of farm

155 management, wastes were applied evenly on the soil surface (surface application), or using a

156 wooden stick, waste was mixed in the top $3-5 \mathrm{~cm}$ of soil (incorporated application). Plastic lids

157 were placed over each microcosm to reduce water evaporation. A non-seeded control set of

158 micrcosms were prepared for each time point, for each waste and PBS, to account for natural

159 bacteria and phage levels. 

incubated continuously at $30^{\circ} \mathrm{C}$ and $20^{\circ} \mathrm{C}$ for $14 \mathrm{~h}$ and $10 \mathrm{~h}$ cycles (day : night), respectively, to simulate summer growing season conditions in the southeastern US. Maintaining water moisture of $25 \%$ was achieved by adding sterile deionized water weekly. Microcosms were weighed when soil moisture was at desired levels and brought to that weight each week. At each time

165 point, each representative microcosm was sacrificed for analysis of bacterial and viral levels.

166 The top 5-7 cm of each microcosm was mixed thoroughly with wooden tongue depressors prior 167 to culture and molecular assays.

\subsection{Cultivation-dependent Enumeration}

169 Prior to microbial analyses, $10 \mathrm{~g}$ of each sample was suspended in $95 \mathrm{~mL}$ of sterile physiological 170 saline in a stomacher bag and stomached for $30 \mathrm{~s}$ prior to serial dilution and plating.

171 Enumeration of $S$. enterica and E. coli O157:H7, was achieved by direct plating to Hektoen

172 Enteric agar (BD-Difco) and Cefixime Tellurite Sorbitol MacConkey (CTSMAC) agar,

173 respectively, and incubated overnight at $35^{\circ} \mathrm{C}$. C. jejuni was enumerated by direct plating to

174 Preston agar (Neogen-Accumedia) containing 5\% horse blood (Hema-Resources; Aurora, OR)

175 and incubated at $42^{\circ} \mathrm{C}$ under microaerophilic conditions for $48 \mathrm{~h}$. L. monocytogenes was direct

176 plated to Oxford agar (Neogen) and incubated for $24-48 \mathrm{~h}$ at $35^{\circ} \mathrm{C}$. C. perfringens was

177 enumerated by membrane filtration on mCP media and incubating at $44.5^{\circ} \mathrm{C}$ overnight. When 178 pathogens could no longer be isolated by direct plating, $1 \mathrm{~g}$ of representative microcosm sample 179 was added to $10 \mathrm{~mL}$ of the respective enrichment broth and incubated $24-48 \mathrm{~h}$ and plated on 180 their respective media and incubation temperatures. S. enterica, E. coli O157, L. monocytogenes, 181 and C. jejuni were enriched using RVR10 (Neogen), ECMUG (Neogen), Fraser (Neogen), and 182 Campy Enrichment Broth (Neogen) and 5\% Sheep Blood TSB, respectively according to previous 
research (McLaughlin et al., 2009). Representative colonies of each isolated bacteria was confirmed via PCR.

Coliphages, MS2 and $\varnothing \mathrm{X} 174$, were enumerated by plaque assays using their respective log- phase E. coli propagation hosts $\left(\sim 10^{6}-10^{7} \mathrm{CFU} \mathrm{ml}{ }^{-1}\right)$. Phages were enumerated by adding $0.1 \mathrm{ml}$ of serial diluted sample with $0.1 \mathrm{ml}$ of fresh exponential growth phase $E$. coli in TSB to $5.0 \mathrm{ml}$ of soft TSA $(0.75 \%$ agar $)$ which had been melted and maintained at $50^{\circ} \mathrm{C}$ in a water-bath. Soft agar mixtures were poured onto full strength TSA and plates were incubated overnight at $35^{\circ} \mathrm{C}$. Counts of PFU were made within $12-16 \mathrm{~h}$.

\subsection{Quantitative PCR}

Immediately following sample collection, $1 \mathrm{~g}$ of each microcosm was homogenized and frozen archived at $-80^{\circ} \mathrm{C}$. DNA was extracted from $0.25 \mathrm{~g}$ of each sample from days $0,7,14,28$ and 60 d using the Qiagen QiAmp DNA stool mini kit (Cat No. 51504) (Qiagen, Victoria, Australia) following the manufacturer's recommended procedure. Reaction mixtures included $2 \mu$ DNA extract (diluted 1:10 or 1:100), 12.5 $\mu$ of the ABI syber green master mix (Applied Biosystems, Foster City, CA), $1.0 \mu \mathrm{l}$ of each associated forward and reverse primer $(10 \mu \mathrm{M})$, and $9.5 \mu \mathrm{l}$ PCR $\mathrm{H}_{2} \mathrm{O}$ for each quantitative PCR (qPCR). Sample inhibition and qPCR optimizations for each assay were performed prior to study commencement or were based on previously published work (Brooks et al., 2014). Dilution was suitable for most samples to remove the effect of inhibition. For samples that contained clay loam soil, $0.5 \mu$ polyvinylpyrrolidone was added per reaction to reduce inhibition associated with clay soils (Koonjul et al., 1999). S. enterica, C. jejuni, E. coli O157:H7, and L. monocytogenes were all quantified using an ABI 7300 real-time PCR system (Applied Biosystems, Foster City, CA). All qPCR reactions were performed using the same 
conditions: $95^{\circ} \mathrm{C}(10 \mathrm{~min}), 40$ repetitions of $95^{\circ} \mathrm{C}(15 \mathrm{~s})$ and $60^{\circ} \mathrm{C}(1 \mathrm{~min})$, and melt-curve analysis at $95^{\circ} \mathrm{C}(15 \mathrm{~s}), 60^{\circ} \mathrm{C}(30 \mathrm{~s})$, and $95^{\circ} \mathrm{C}(15 \mathrm{~s})$. Positive, negative, and spike (inhibition) controls were included in every qPCR plate. Each reaction was set up in duplicate and amplification signals were quantified with a PCR-based standard curve and confirmed using melt-curve analysis. Standard control DNA was extracted from pure colony cultures and PCRamplified, purified, quantified, and diluted from $\sim 10^{5}$ to 1 genomic unit per $\mu \mathrm{l}\left(\mathrm{GU} \mu \mathrm{l}^{-1}\right)$.

Standard curves were required to have an $\mathrm{r}^{2}$ of 0.98 . An acceptable positive was only considered positive if both duplicates had $\mathrm{Ct}$ values less than the negative control and spike samples were within $+/-25 \%$ of the positive control. Table 2 lists the genetic markers, primer sequences and sizes of each target analyzed.

\subsection{Inactivation Rates}

Inactivation rates were calculated using a first order survival curve determined by $\log _{10}\left(\mathrm{~N}_{\mathrm{t}} / \mathrm{N}_{0}\right)=$ $\mathrm{kt}+\mathrm{b}$; where $\mathrm{N}_{\mathrm{t}}$ is the titer $\left(\mathrm{CFU}, \mathrm{PFU}\right.$, or $\mathrm{GU} \mathrm{g}^{-1}$ ) at time $\mathrm{t}(\mathrm{d}), \mathrm{N}_{0}$ is the original titer (CFU, $\mathrm{PFU}$, or $\mathrm{GU} \mathrm{g}^{-1}$ ) at $\mathrm{t}=0 \mathrm{~d}, \mathrm{k}$ is the inactivation rate based on the slope of decay of each microorganism, and $\mathrm{b}$ is the $\mathrm{y}$-intercept for each organism-waste-soil treatment combination.

\subsection{Statistical Analysis}

SAS Enterprise Guide 4.3 (SAS Institute, Cary, NC) was used for all statistical analyses.

Geometric means were calculated prior to analysis. Prior to analysis all non-seeded microcosm bacterial or phage levels were subtracted from seeded levels per time point. This would account for any natural populations within each respective waste-residual. When enrichment detection was used for bacterial detection, the detection limit of $100 \mathrm{CFU} \mathrm{g}^{-1}$ was used for statistical purposes. A mixed model analysis was performed for all cultivated bacteria and phages and 
227 qPCR assayed bacteria (S. enterica, E. coli O157:H7, L. monocytogenes, and C. jejuni) to

228 determine the effect of waste residual, soil type, farm management and their interactions (waste

229 residual $*$ soil and waste residual * management) on inactivation rates (k values). This was

230 conducted for both cultivation-dependent and -independent assays. Waste residuals were

231 analyzed separately to determine if soil or management contributed to each microbial

232 parameter's persistence. Means were compared with difference of least squares means. A

233 standard ANOVA was performed to compare calculated inactivation rates associated with waste

234 residual, soil type, management and assay. Differences in phage enumeration between waste

235 residuals, soil types and management practices were compared in paired t-tests. Differences

236 were considered statistically significant at a probability level of $p \leq 0.05$.

\section{3. RESULTS}

\section{$238 \quad 3.1$ Effect of waste, soil, time, and management}

239 In general at least one of the test variables: waste-residual, soil type, or time significantly

240 affected the decay rates of all bacteria and phage tested $(\mathrm{p}<0.05)$, whether assayed via cultivation

241 or qPCR (Table 3). Additionally, the interactions of waste-residual*soil, waste-

242 residual*management, and waste-residual*soil*management significantly affected inactivation

243 rates for nearly all bacteria and phage tested $(\mathrm{p}<0.05)$. Table 3 provides a summary of all

244 significant effects and mean inactivation rates, averaged across all experiments.

\section{3.1.1 Effect of Waste Residual}

Overall, waste-residual significantly affected all tested organisms’ inactivation rates (i.e.

247 k-rates), though differences in k-rates were minor within $C$. jejuni inactivation rates. $C$.

248 perfringens inactivation was negatively affected (e.g. more inactivation or less persistence) by 
249 the presence of cattle waste compared with all other matrices, nearly 1 order of magnitude

250 difference. S. enterica inactivation rates were positively affected (e.g. less inactivation or longer

251 persistence) in biosolids and cattle waste-residuals by nearly 2-fold compared with swine

252 effluent and PBS control $(\mathrm{p}<0.05)$; there was no difference between cattle and biosolids

253 ( $\mathrm{p}<0.05)$. Generally, S. enterica persisted longer $(\mathrm{p}<0.0001)$ in cattle manure and biosolids than

254 in other wastes with mean k-values ranging from -0.0369 to -0.0757 , while the liquid matrices

255 were greater than -0.1362. L. monocytogenes inactivation rates were also significantly affected

256 by biosolids and cattle waste-residuals ( $p<0.05$ ); inactivation rates averaged -0.1835 to -0.2584

257 for solid wastes, while liquid matrices averaged -0.4579 , approximately a 2-fold increase in

258 inactivation. Both phage, in general, were inactivated more readily by cattle than biosolids

259 wastes, while both liquid matrices were nearly the same (data not shown). Non-cultivated E. coli

$260 \mathrm{O} 157$ and $C$. jejuni were significantly affected by $(\mathrm{p}<0.05)$ waste-residual. Overall, solid wastes

261 negatively affected inactivation rates associated with $C$. jejuni and E. coli O157, and though not

262 significant, also appeared to similarly affect cultivation-independent L. monocytogenes and $S$.

263 enterica (Table 3).

264 3.1.2 Effect of Soil Type and Management

Soil type had fewer effects on cultivated organisms. For instance, sandy loam soil, in

266 general, negatively affected inactivation rates more so than clay loam for cultivated $L$.

267 monocytogenes, OX174 and MS2; on the contrary, C. jejuni was negatively affected by clay

268 loam soil (Table 3). Clay loam soil was also found to negatively impact $C$. perfringens

269 inactivation rates $(\mathrm{p}<0.05)$ by nearly 3 -fold. Management affected cultivated $S$. enterica, $C$.

270 perfringens, E. coli $\mathrm{O} 157$, and MS2 (p<0.05). E. coli $\mathrm{O} 157$ inactivation was negatively affected 
271 by incorporating wastes into soil by approximately $0.1 \log \mathrm{d}^{-1}$, while conversely Salmonella

272 inactivation rates were negatively affected by surface-applied $(\mathrm{p}<0.05)$.

274 demonstrated that clay loam soil had a negative impact $(\mathrm{p}<0.05)$ on Campylobacter jejuni and $E$.

275 coli O157, while no effect was noted for L. monocytogenes or S. enterica. Incorporating waste-

276 residuals into soil appeared to negatively impact non-cultivated $S$. enterica inactivation rates by

277 2-fold, while not incorporating waste-residuals negatively impacted inactivation rates by $0.01 \log$

$278 \mathrm{~d}^{-1}$ for L. monocytogenes (Table 3). C. jejuni k rates were negatively impacted by surface-applied

279 by approximately $0.01 \log \mathrm{d}^{-1}$, while $E$. coli $\mathrm{O} 157$ was not affected.

\section{$280 \quad 3.1 .3$ Effect of Main Effect Interactions}

The interaction of waste-residual*soil, waste-residual*management, and waste-

282 residual*soil*management significantly affected most tested organisms (Table 3). Table 4 shows

283 individual permutations of organism*waste-residual*soil*management. E. coli $\mathrm{O} 157$

284 inactivation rates in biosolids with either soil type were more negative by at least $0.1 \log \mathrm{d}^{-1}$

285 compared with cattle manure in clay loam soil, with the exception when cattle manure was

286 incorporated into clay loam soil $(\mathrm{k}=-0.6772)$. Similarly, cattle manure*clay loam soil had a more

287 negative effect on $C$. perfringens inactivation rates, often times by $-0.1 \log \mathrm{d}^{-1}$ compared to liquid

288 x soil. Waste-residual*management negatively affected inactivation of Salmonella $(\mathrm{p}<0.05)$

289 within liquid matrices more than the solid wastes with the exception of clay loam

290 soil*incorporated.

2913.2 Cultivation-dependent vs. -independent 
293 affected by assay type. Almost exclusively, cultivation-based inactivation rates were more 294 negative than cultivation-independent-based rates $(\mathrm{p}<0.05)$ (Table 3 and 4). Cultivation-based 295 inactivation rates were negatively affected by nearly 2 fold, from -0.07 to -0.13 for

296 Campylobacter. E. coli $\mathrm{O} 157$ and S. enterica inactivation rates behaved similarly, while Listeria 297 monocytogenes $\mathrm{k}-$ rates were most affected with a mean of -0.33 for cultivation-based 298 inactivation rates to $-0.04 \log \mathrm{d}^{-1}$ for cultivation-independent inactivation rates.

300 coli O157, and L. monocytogenes provide a comparison of these two assay types (Table 5). S. 301 enterica was very similar for both cultivation-dependent and -independent detection for the first 3022 weeks. For instance, cattle manure in sandy loam had similar detection with ratios close to 1:1 303 (CFU:GU). At d14, cultivation detection was at or below detection limits in biosolids, but the 304 cultivation-independent techniques were still able to quantify S. enterica markers. For example, 305 Salmonella was detected at a 1:10 ratio when surface applied via cattle manure to clay loam soil. 306 However, S. enterica (cattle manure) was detected through cultivation-enrichment for a longer 307 time period. Cultivation-dependent data for E. coli $\mathrm{O} 157$ and L. monocytogenes were favored at 308 a ratio of 15 to 1 for initial levels, when waste was surface applied to sandy loam soil. By day 60 309 the molecular markers were no longer detected for E. coli but cultivation data indicated E. coli 310 was still viable through enrichment methods (10:1). L. monocytogenes was not present through 311 cultivation-dependent detection but molecular markers were detected (1:100). 
313 According to USDA-AMS (2000), manure can be applied to food crops with a stipulated post314 application harvest delay of 90 to 120 days. Overall, based on the current study, the effect of 315 waste-residual was the most likely of the tested variables to influence inactivation rates (e.g. k 316 constants), followed closely by soil-type, and management. This makes intuitive sense, given the 317 highly complex nature of waste-residuals and influence of feed, animal type, antibiotics, and 318 municipality (Hutchison et al., 2005; Brooks et al., 2012). Additionally, the presence of 319 relatively high solid material such as cattle manure and biosolids would inherently bias towards 320 certain organisms. This was not always the case in the current study. The effects of each 321 variable were not "globally" constant, nor predictable, with rates, organism and soil-type 322 dependent. Simply viewing the mean effect of solid waste-residuals (i.e. cattle manure and 323 biosolids), the current data shows positively affected inactivation rates for cultivated $S$. enterica 324 and L. monocytogenes. Meanwhile E. coli $\mathrm{O} 157: \mathrm{H} 7$ and $C$. perfringens inactivation rates were 325 negatively affected by cattle manure. Variability in the effect of solid material has been shown 326 in previous studies by Hutchison et al. (2005) with liquid and solid dairy manure selecting for 327 salmonellae and L. monocytogenes, respectively. Though the current study did not compare 328 liquid and solid wastes from the same species, Salmonella k-rates were slower by 1 order of 329 magnitude in solid wastes. For the most part limited inactivation of Clostridium perfringens, 330 based on waste type was expected, owing to its ability to form spores capable of enduring 331 environmental changes that vegetative cells cannot. This was the case in most permutations, with 332 the exception of cattle manure surface-applied on clay loam, $\mathrm{k}=-0.1758$, whereas other 333 combinations had at least 1 order of magnitude slower k-rates than most bacteria or phage. Many of the interactions were organism and experimental-variable specific. The 335 interaction of organism*waste-residual*soil-type or *management significantly affected 
inactivation rates. For example, results of the current study suggest that if $S$. enterica were present at high levels in land-applied manure, it may persist longer in soil than the recommended waiting period for harvesting food crops. This may only be reasonably plausible if assuming ideal conditions of moisture and organic matter (e.g. high solid wastes) are present; if a field is dry and conditions are unfavorable, it's reasonable to assume most pathogens begin rapid die off (Hutchison et al., 2005; Brooks et al., 2012). Inactivation rates established in the current study were, however, based on initially high levels $\left(10^{6} \mathrm{CFU} \mathrm{g}{ }^{-1}\right)$ of pathogens, a caveat of laboratory studies (Hutchison et al., 2004). S. enterica may remain viable beyond harvest delays, assuming cattle manure surface applied to sandy loam soil at starting levels of $1.6 \times 10^{2}-2.5 \times 10^{3} \mathrm{CFU} \mathrm{g}^{-1}$ (Hutchison et al., 2005; Volkova et al., 2011). Applying the current k-rates, indicates S. enterica 346 may remain viable beyond the recommended post-application harvest delay. Longer persistence of S. enterica in cattle manure than in other residuals may be due to a lack of chemical or physical attenuating factors present in other high solid content wastes, such as biosolids. Biosolids are commonly lime stabilized to control pathogen levels and vector attraction (e.g. insects)(Bean et al., 2007; Hansen et al., 2007), though the increased pH (Bean et al., 2007) and the reduced moisture (Opara et al., 1992) did not increase inactivation. On the other hand, liquid matrices increased inactivation by nearly 1 order of magnitude $\left(\log \mathrm{d}^{-1}\right)$ in the case of cultivated S. enterica; this trend held true for most bacteria/waste combinations.

On the other hand, inactivation of the two phage indicators was more unpredictable, with biosolids and sandy loam soil positively affecting MS2 inactivation while negatively affecting $\emptyset \mathrm{X} 174$ inactivation. This may be due to differences in surface receptor attachment in either 357 matrix. Decay rates of MS2 phage in biosolids, in the present study, are in agreement with those 
cattle manure potentially due to increased iron oxide. The presence of a suitable E. coli host in biosolids (Yang and Griffiths, 2013) may also partially offset phage degradation. Straub et al. (1992) reported that MS2 was not affected by clay or sandy soils. In the present study, inactivation rates of MS2 phage in all wastes were much slower when applied to sandy loam than to clay soil. It is possible that phage adherence to clay particles (Sobsey et al., 1980) made it more difficult to detect MS2 in the present study.

The effect of waste incorporation was not an obvious predictor of inactivation rates. For example, $S$. enterica inactivation rates were decreased by waste-incorporation in certain scenarios, while $E$. coli $\mathrm{O} 157$ rates were increased. It was expected that all waste incorporation would decrease inactivation. However, the effect of management was also an interactive effect coupled with waste-residual and soil-type. Several mechanisms may explain the effect of application method on $S$. enterica survival. For instance $S$. enterica has been shown to be more recalcitrant to the effects of desiccation (Koseki et al., 2015). Incorporating the waste reduces desiccation of the bacteria allowing for prolonged survival, but also promotes interaction with soil microbes, which may explain the negative effect of incorporation. Others, like $L$. monocytogenes, were generally not affected by management practice, possibly owing to the thick peptidoglycan wall surrounding Gram + bacterial cells, which can resist desiccation. Additionally, Listeria spp. are known to be present in many soil environments (Linke et al., 2014). Study limitations such as the lack of wind air desiccation and UV light on the microcosms may have influenced the variable effect of waste-residual (Hutchison et al. 2005). microorganisms in environmental samples. Cultivation-dependent is cost-effective, simple, and can be used to analyze large sample aliquots; however the time from sample to results is longer 
382 and not all organisms can be cultivated. Cultivation-independent methods via qPCR overcome

383 these limitations but increased costs, ability to analyze only small sample aliquots, and the caveat

384 that genetic markers can persist longer than viable pathogens which leads to positive assays for

385 inactivated bacteria and viruses. Quantitative PCR methods are subject to issues distinguishing

386 viable from inactive cells, although some chemistries are providing this distinction, with caveats,

387 via propidium monoazide (Kim and Ko, 2012).

Notwithstanding these limitations, many laboratories are turning towards qPCR for

389 pathogen detection, which ultimately will affect the way inactivation rates are determined,

390 interpreted, and utilized. Overall, in the current study, inactivation rates yielded by qPCR were

391 slower than comparable cultivated rates. Klein et al. (2011) noted that qPCR data for

392 microorganisms yielded slower decay rates than cultivation data, which corroborates findings in

393 the present study. For example, mean inactivation rates for S. enterica were significantly

394 different $(\mathrm{p}<0.05)$ for cultivation-independent $(\mathrm{k}=-0.06)$ and - dependent $(\mathrm{k}=-0.010)$; E. coli

$395 \mathrm{O} 157$ fared similarly k=-0.07 and -0.13 , respectively. The biggest effect of assay was on $C$.

396 jejuni inactivation rates with cultivation-independent $(\mathrm{k}=-0.03)$ and - dependent $(\mathrm{k}=-0.68)$.

397 Additionally, the effect of time influenced the effectiveness of each respective method. As seen

398 in Table 6, the closer a ratio approaches 1.0 at a specific time point, the more corroborative the

399 results were. Typically, the ratios approach $+/-25 \%$ of each other as time approaches 0 , though

400 many combinations held larger discrepancies at early time points as well, most likely owing to

401 difficulty in either cultivation-dependent or -independent methods. Additionally, multiple copies

402 of a gene within a cell can lead to over-inflated qPCR values, though aside from the

403 Campylobacter primer pair, no other primer target was associated with multiple genomic copies. 
The effect of assay was also dependent on combinations of experimental variables. The

405

406

407

408

409

410

411

412

413

414

415

416

417

418 presence of clay loam soil and solid waste-residuals selected for more negative inactivation rates via qPCR, whereas that effect may not have been evident with cultivation (Table 4). For instance, the cultivation-independent k-rates for $E$. coli $\mathrm{O} 157$ were -0.026 and -0.1 , respectively for cattle*sandy loam*non incorporation and cattle*clay loam*non incorporation. Comparable cultivation-dependent k-rates were -0.02 and -0.03 , respectively. In other instances, k-rates were similar between both methodologies, such as for S. enterica, often times nearly identical or within 2-fold (Table 4). The discrepancy in k-rates varied from 2-fold to 10-fold depending on the scenario, and may be influenced by a combination of ease of cultivation, thus accurately depicting viable cells, but most likely was a result of detection of VBNC DNA. The detection of VBNC DNA most likely under represented true inactivation rates. In some instances, cultivation was the problem, such as with $C$. jejuni, in which cultivation-independent approaches most likely yielded the most accurate k-rate, though most likely facilitated by the detection of VBNC DNA. C. jejuni is difficult to detect in a complex population (ACMF, 2010) and can be more readily detected using cultivation-independent methods (McLaughlin et al., 2009).

In summary, this study looked at the effect of waste residuals on pathogenic bacteria and viruses under various microcosm-simulated scenarios. This study compared the effect of: waste residual; soil type and management practice; model interactions of each; and detection methods on inactivation rates, k-rates. The current study investigated the effect of each of these variables and determined interactions to be very situation specific.

For most bacterial and phage inactivation constants, one or both solid wastes positively influenced inactivation rates, though there were exceptions. On the contrary, the presence of solid waste led to more negative inactivation rates when determined via cultivation-independent 
427 methodologies. Soil type and management practice had variable effects on microbe inactivation

428 rate, with clay loam soil negatively selecting for cultivation-independent k-rates, while

429 incorporating wastes did not positively influence inactivation rates. The inactivation rates

430 determined from cultivation-dependent and -independent analyses weren't always in agreement,

431 particularly as microcosm time progressed beyond 14 days and nuances of each method were

432 apparent. When practical, the complementary strengths and weaknesses of both methods suggest

433 the use of cultivation-dependent and-independent methods in environmental studies. At the

434 very least, the appropriate of use of either approach should be employed based on pathogen

435 specific study objectives (e.g. qPCR for detection of C. jejuni). Additionally, it's more apparent

436 that interpreting results from a study utilizing only one method must be more heavily scrutinized

437 to determine if the inactivation rates are applied correctly. For instance, application of qPCR-

438 derived k-rates may be more appropriate for recalcitrant but difficult to cultivate bacteria such as

439 Listeria, especially beyond 30 days. Whereas, S. enterica k-rates may be more represented by

440 cultivation-dependent methods, even up to 60 days. Perhaps the application of CFU:GU ratios,

441 such as those presented in Table 5, can be used as corrective factors if only one methodology is

442 utilized, though the implication of the current study suggest that specific

443 organism/soil/waste/environmental combinations will affect each ratio. The advantages offered

444 by each detection method can aid in the selection of more appropriate inactivation constants and

445 improved risk models for pathogens in the environment. Differences in microbial decay rates

446 determined by cultivation-dependent and -independent methods in this study suggest that more

447 research is needed to reconcile these approaches and develop improved microbial survival data

448 for more accurate risk assessments.

\section{Acknowledgements}


450 This research was funded by Agriculture and Food Research Initiative Grant 3556 from the 451 USDA National Institute of Food and Agriculture. We appreciate our cooperators for allowing 452 us to collect cattle manure, swine effluent and municipal biosolids from their facilities. In 453 addition, a special thanks to Cindy Smith and Renotta Smith, for technical assistance with the 454 research.

455 
Advisory Committee on the Microbiological Safety of Food (ACMSF). The Isolation Of Campylobacter Spp From Food And Environmental Samples. Advisory Committee On The Microbiological Safety Of Food, 2010.

Abdelwhab EM, Grund C, Aly MM, Beer M, Harder TC, Hafez HM. Multiple dose vaccination with heterologous $\mathrm{H} 5 \mathrm{~N} 2$ vaccine: immune response and protection against variant clade 2.2.1 highly pathogenic avian influenza H5N1 in broiler breeder chickens. Vaccine 2011; 29: 6219-25.

Bean CL, Hansen JJ, Margolin AB, Balkin H, Batzer G, Widmer G. Class B alkaline stabilization to achieve pathogen inactivation. Int J Environ Res Public Health 2007; 4: 53-60.

Berger CN, Sodha SV, Shaw RK, Griffin PM, Pink D, Hand P, et al. Fresh fruit and vegetables as vehicles for the transmission of human pathogens. Environ Microbiol 2010; 12: 238597.

Bhattarai R, Kalita PK, Yatsu S, Howard HR, Svendsen NG. Evaluation of compost blankets for erosion control from disturbed lands. J Environ Manage 2011; 92: 803-12.

Brooks JP, McLaughlin MR, Gerba CP, Pepper IL. Land application of manure and Class B biosolids: an occupational and public quantitative microbial risk assessment. J Environ Qual 2012; 41: 2009-23.

Brooks JP, Tanner BD, Josephson KL, Gerba CP, Haas CN, Pepper IL. A national study on the residential impact of biological aerosols from the land application of biosolids. J Appl Microbiol 2005; 99: 310-22.

Colinon C, Deredjian A, Hien E, Brothier E, Bouziri L, Cournoyer B, et al. Detection and enumeration of Pseudomonas aeruginosa in soil and manure assessed by an ecfX qPCR assay. J Appl Microbiol 2013; 114: 1734-49.

D'Souza DH, Su X. Efficacy of chemical treatments against murine norovirus, feline calicivirus, and MS2 bacteriophage. Foodborne Pathog Dis 2010; 7: 319-26.

Choffnes ER, Relman DA, Olsen L,Hutton R, Rapporteurs AM. IMPROVING FOOD SAFETY THROUGH A ONE HEALTH APPROACH. National Academy of Sciences, Washington, D.C., 2012.

Fakruddin M, Mannan KS, Andrews S. Viable but Nonculturable Bacteria: Food Safety and Public Health Perspective. ISRN Microbiol 2013; 2013: 703813.

Freestone P, Lyte M. Stress and microbial endocrinology: prospects for ruminant nutrition. Animal 2010; 4: 1248-57.

Gerba CP, Smith JE, Jr. Sources of pathogenic microorganisms and their fate during land application of wastes. J Environ Qual 2005; 34: 42-8.

Haas CN, Rose JB, Gerba CP. Quantitative Microbial Risk Assessment. New York, NY: John Wiley \& Sons, 1999.

Hansen JJ, Warden PS, Margolin AB. Inactivation of adenovirus type 5, rotavirus Wa and male specific coliphage (MS2) in biosolids by lime stabilization. Int J Environ Res Public Health 2007; 4: 61-7.

Holley RA, Arrus KM, Ominski KH, Tenuta M, Blank G. Salmonella survival in manure-treated soils during simulated seasonal temperature exposure. J Environ Qual 2006; 35: 1170-80. 
Hutchison ML, Walters LD, Avery SM, Munro F, Moore A. Analyses of livestock production, waste storage, and pathogen levels and prevalences in farm manures. Appl Environ Microbiol 2005; 71: 1231-6.

Hutchison ML, Walters LD, Avery SM, Synge BA, Moore A. Levels of zoonotic agents in British livestock manures. Lett Appl Microbiol 2004; 39: 207-14.

Inglis GD, McAllister TA, Larney FJ, Topp E. Prolonged survival of Campylobacter species in bovine manure compost. Appl Environ Microbiol 2010; 76: 1110-9.

Islam M, Morgan J, Doyle MP, Phatak SC, Millner P, Jiang X. Fate of Salmonella enterica serovar Typhimurium on carrots and radishes grown in fields treated with contaminated manure composts or irrigation water. Appl Environ Microbiol 2004; 70: 2497-502.

Katz BD, Margolin AB. Inactivation of hepatitis A HM-175/18f, reovirus T1 Lang and MS2 during alkaline stabilization of human biosolids. J Appl Microbiol 2007; 103: 2225-33.

Kim SY, Ko G. Using propidium monoazide to distinguish between viable and nonviable bacteria, MS2 and murine norovirus. Lett Appl Microbiol 2012; 55: 182-8.

Klein M, Brown L, Ashbolt NJ, Stuetz RM, Roser DJ. Inactivation of indicators and pathogens in cattle feedlot manures and compost as determined by molecular and culture assays. FEMS Microbiol Ecol 2011; 77: 200-10.

Koonjul PK, Brandt WF, Farrant JM, Lindsey GG. Inclusion of polyvinylpyrrolidone in the polymerase chain reaction reverses the inhibitory effects of polyphenolic contamination of RNA. Nucleic Acids Res 1999; 27: 915-6.

Koseki S, Nakamura N, Shiina T. Comparison of desiccation tolerance among Listeria monocytogenes, Escherichia coli O157:H7, Salmonella enterica, and Cronobacter sakazakii in powdered infant formula. J Food Prot 2015; 78: 104-10.

Lang NL, Bellett-Travers MD, Smith SR. Field investigations on the survival of Escherichia coli and presence of other enteric micro-organisms in biosolids-amended agricultural soil. $\mathbf{J}$ Appl Microbiol 2007; 103: 1868-82.

Lang NL, Smith SR. Influence of soil type, moisture content and biosolids application on the fate of Escherichia coli in agricultural soil under controlled laboratory conditions. J Appl Microbiol 2007; 103: 2122-31.

Linke K, Ruckerl I, Brugger K, Karpiskova, R, Walland J, Muri-Klinger S, Tichy A., Wagner M, and Stessl B. Reservoirs of Listera species in three environmental ecosystems. Appl Environ Microbiol 2014; 80: 5583-5592.

Locatelli A, Spor A, Jolivet C, Piveteau P, Hartmann A. Biotic and abiotic soil properties influence survival of Listeria monocytogenes in soil. PLoS One 2013; 8: e75969.

McLaughlin MR, Brooks JP, Adeli A. Characterization of selected nutrients and bacteria from anaerobic swine manure lagoons on sow, nursery, and finisher farms in the Mid-South USA. J Environ Qual 2009; 38: 2422-30.

Moore JC, Gross EA. Update on emerging infections: news from the Centers for Disease Control and Prevention. Surveillance for foodborne disease outbreaks-United States, 2006. Ann Emerg Med 2010; 55: 47-9.

Olsen SJ, MacKinnon LC, Goulding JS, Bean NH, Slutsker L. Surveillance for foodbornedisease outbreaks--United States, 1993-1997. MMWR CDC Surveill Summ 2000; 49: 162.

Opara OO, Carr LE, Russek-Cohen E, Tate CR, Mallinson ET, Miller RG, et al. Correlation of water activity and other environmental conditions with repeated detection of Salmonella contamination on poultry farms. Avian Dis 1992; 36: 664-71. 
Rogers SW, Donnelly M, Peed L, Kelty CA, Mondal S, Zhong Z, et al. Decay of bacterial pathogens, fecal indicators, and real-time quantitative PCR genetic markers in manureamended soils. Appl Environ Microbiol 2011; 77: 4839-48.

Scallan E, Hoekstra RM, Angulo FJ, Tauxe RV, Widdowson MA, Roy SL, et al. Foodborne illness acquired in the United States--major pathogens. Emerg Infect Dis 2011; 17: 7-15.

Sobsey MD, Dean CH, Knuckles ME, Wagner RA. Interactions and survival of enteric viruses in soil materials. Appl Environ Microbiol 1980; 40: 92-101.

Straub TM, Pepper IL, Gerba CP. Persistence of viruses in desert soils amended with anaerobically digested sewage sludge. Appl Environ Microbiol 1992; 58: 636-41.

Toth JD, Aceto HW, Rankin SC, Dou Z. Survival characteristics of Salmonella enterica serovar Newport in the dairy farm environment. J Dairy Sci 2011; 94: 5238-46.

USDA-AMS. National Organic Program. 7 CFR Part 205 USDA-AMS, Washington, D.C., 2000.

USDA-NASS. Census of Agriculture. 2012, 2011.

USEPA. A guide to the biosolids risk assessments for the EPA Part 503 Rule. 1995.

Viau E, Bibby K, Paez-Rubio T, Peccia J. Toward a consensus view on the infectious risks associated with land application of sewage sludge. Environ Sci Technol 2011; 45: 545969.

Volkova VV, Wills RW, Hubbard SA, Magee DL, Byrd JA, Bailey RH. Risk factors associated with detection of Salmonella in broiler litter at the time of new flock placement. Zoonoses Public Health 2011; 58: 158-68.

Wei J, Jin Y, Sims T, Kniel KE. Manure- and biosolids-resident murine norovirus 1 attachment to and internalization by Romaine lettuce. Appl Environ Microbiol 2010; 76: 578-83.

Wong K, Onan BM, Xagoraraki I. Quantification of enteric viruses, pathogen indicators, and Salmonella bacteria in class B anaerobically digested biosolids by culture and molecular methods. Appl Environ Microbiol 2010; 76: 6441-8.

Yang Y, Griffiths MW. Comparative persistence of subgroups of F-specific RNA phages in river water. Appl Environ Microbiol 2013; 79: 4564-7.

You Y, Rankin SC, Aceto HW, Benson CE, Toth JD, Dou Z. Survival of Salmonella enterica serovar Newport in manure and manure-amended soils. Appl Environ Microbiol 2006; 72: 5777-83. 
Table 1 Recently published decay rates (k-rates) involving common indicator bacteria and phage as well as select pathogens under specific moisture, waste, soil, and management practices.

\begin{tabular}{|c|c|c|c|c|c|c|c|}
\hline Pathogen & $\begin{array}{c}\text { k-rate } \\
\left(\log d^{-1}\right)\end{array}$ & Waste & Moisture & Soil & Management & $\begin{array}{l}\text { Temp } \\
\left({ }^{\circ} \mathrm{C}\right)\end{array}$ & Reference \\
\hline \multirow[t]{2}{*}{ Coliforms } & -0.1 & cattle manure (compost) & $51-57 \%$ & na & na & $25-34$ & Klein et al. 2011 \\
\hline & -0.14 & cattle manure (stockpile) & $51-57 \%$ & na & na & $33-39$ & Klein et al. 2011 \\
\hline \multirow[t]{6}{*}{ E. coli } & -0.05 & biosolids (DMAD moist) & $32 \%$ & silty clay & incorporated & 15 & Lang et al. 2007 \\
\hline & -0.05 & biosolids (DMAD moist) & $21.30 \%$ & sandy loam & incorporated & 15 & Lang et al. 2007 \\
\hline & -0.005 & biosolids (DMAD air-dried) & $8.60 \%$ & silty clay & incorporated & 15 & Lang et al. 2007 \\
\hline & -0.01 & biosolids (DMAD air-dried) & $6.80 \%$ & sandy loam & incorporated & 15 & Lang et al. 2007 \\
\hline & -0.041 & cattle manure (compost) & $51-57 \%$ & na & na & $25-34$ & Klein et al. 2011 \\
\hline & -0.082 & cattle manure (compost) & $51-57 \%$ & na & na & $25-34$ & Klein et al. 2011 \\
\hline \multirow[t]{8}{*}{ E. coli (EPA-EC23S) } & -0.26 & swine lagoon effluent & FC $60 \%$ & clay loam & incorporated & 25 & Rogers et al. 2011 \\
\hline & -0.16 & swine lagoon effluent & FC $80 \%$ & clay loam & incorporated & 25 & Rogers et al. 2011 \\
\hline & -0.026 & cattle manure & FC $60 \%$ & clay loam & incorporated & 25 & Rogers et al. 2011 \\
\hline & -0.041 & cattle manure & FC $80 \%$ & clay loam & incorporated & 25 & Rogers et al. 2011 \\
\hline & -0.4 & swine lagoon effluent & FC $60 \%$ & clay loam & incorporated & 25 & Rogers et al. 2011 \\
\hline & -0.28 & swine lagoon effluent & FC $80 \%$ & clay loam & incorporated & 25 & Rogers et al. 2011 \\
\hline & -0.33 & cattle manure & FC $60 \%$ & clay loam & incorporated & 25 & Rogers et al. 2011 \\
\hline & -0.37 & cattle manure & FC $80 \%$ & clay loam & incorporated & 25 & Rogers et al. 2011 \\
\hline \multirow[t]{2}{*}{ MS2 phage } & -0.629 & biosolids & $30 \%$ & clay loam & incorporated & 27 & Straub et al. 1992 \\
\hline & -0.652 & biosolids & $30 \%$ & sandy & incorporated & 27 & Straub et al. 1992 \\
\hline \multirow{4}{*}{$\begin{array}{l}\text { S. enterica serovar } \\
\text { Typhimurium/pDs }\end{array}$} & -0.84 & swine lagoon effluent & FC $60 \%$ & clay loam & incorporated & 25 & Rogers et al. 2011 \\
\hline & -0.33 & swine lagoon effluent & FC $80 \%$ & clay loam & incorporated & 25 & Rogers et al. 2011 \\
\hline & -0.81 & cattle manure & FC $60 \%$ & clay loam & incorporated & 25 & Rogers et al. 2011 \\
\hline & -0.76 & cattle manure & FC $80 \%$ & clay loam & incorporated & 25 & Rogers et al. 2011 \\
\hline \multirow[t]{8}{*}{ Salmonella (6 strains) } & -0.0908 & swine lagoon effluent & FC $80 \%$ & sandy & surface & $25-4$ & Holley et al. 2006 \\
\hline & -0.0682 & swine lagoon effluent & FC $80 \%$ & sandy & incorporated & $25-4$ & Holley et al. 2006 \\
\hline & -0.0601 & swine lagoon effluent & FC $80 \%$ & clay loam & surface & $25-4$ & Holley et al. 2006 \\
\hline & -0.0584 & swine lagoon effluent & FC $80 \%$ & clay loam & incorporated & $25-4$ & Holley et al. 2006 \\
\hline & -0.1373 & swine lagoon effluent & FC $60 \%$ & sandy & surface & $25-4$ & Holley et al. 2006 \\
\hline & -0.1358 & swine lagoon effluent & FC $60 \%$ & sandy & incorporated & $25-4$ & Holley et al. 2006 \\
\hline & -0.1109 & swine lagoon effluent & FC $60 \%$ & clay & surface & $25-4$ & Holley et al. 2006 \\
\hline & -0.1105 & swine lagoon effluent & FC $60 \%$ & clay & incorporated & $25-4$ & Holley et al. 2006 \\
\hline Salmonella Newport & -0.0697 & cattle manure & FC $90 \%$ & sandy silt loam & incorporated & 24 & Toth et al. 2011 \\
\hline Salmonella spp. & -0.11 & swine lagoon effluent & FC $60 \%$ & clay loam & incorporated & 25 & Rogers et al. 2011 \\
\hline
\end{tabular}




\begin{tabular}{llllllll}
\hline (ttrRSBCA) & & & & & & & \\
& -0.072 & swine lagoon effluent & FC 80\% & clay loam & incorporated & 25 & Rogers et al. 2011 \\
& -0.34 & cattle manure & FC 60\% & clay loam & incorporated & 25 & Rogers et al. 2011 \\
& -0.26 & cattle manure & FC 80\% & clay loam & incorporated & 25 & Rogers et al. 2011 \\
\hline
\end{tabular}


Table 1 continued: Published decay rates

\begin{tabular}{|c|c|c|c|c|c|c|c|}
\hline Pathogen & $\begin{array}{c}\text { k-rate } \\
\left(\log d^{-1}\right)\end{array}$ & Waste & Moisture & Soil & Management & $\begin{array}{c}\text { Temp } \\
\left({ }^{\circ} \mathrm{C}\right)\end{array}$ & Reference \\
\hline \multirow[t]{2}{*}{ Coliforms } & -0.1 & cattle manure (compost) & $51-57 \%$ & na & na & $25-34$ & Klein et al. 2011 \\
\hline & -0.14 & cattle manure (stockpile) & $51-57 \%$ & na & na & $33-39$ & Klein et al. 2011 \\
\hline \multirow[t]{6}{*}{ E. coli } & -0.05 & biosolids (DMAD moist) & $32 \%$ & silty clay & incorporated & 15 & Lang et al. 2007 \\
\hline & -0.05 & biosolids (DMAD moist) & $21.30 \%$ & sandy loam & incorporated & 15 & Lang et al. 2007 \\
\hline & -0.005 & biosolids (DMAD air-dried) & $8.60 \%$ & silty clay & incorporated & 15 & Lang et al. 2007 \\
\hline & -0.01 & biosolids (DMAD air-dried) & $6.80 \%$ & sandy loam & incorporated & 15 & Lang et al. 2007 \\
\hline & -0.041 & cattle manure (compost) & $51-57 \%$ & na & na & $25-34$ & Klein et al. 2011 \\
\hline & -0.082 & cattle manure (compost) & $51-57 \%$ & na & na & $25-34$ & Klein et al. 2011 \\
\hline \multirow[t]{8}{*}{ E. coli (EPA-EC23S) } & -0.26 & swine lagoon effluent & FC $60 \%$ & clay loam & incorporated & 25 & Rogers et al. 2011 \\
\hline & -0.16 & swine lagoon effluent & FC $80 \%$ & clay loam & incorporated & 25 & Rogers et al. 2011 \\
\hline & -0.026 & cattle manure & FC $60 \%$ & clay loam & incorporated & 25 & Rogers et al. 2011 \\
\hline & -0.041 & cattle manure & FC $80 \%$ & clay loam & incorporated & 25 & Rogers et al. 2011 \\
\hline & -0.4 & swine lagoon effluent & FC $60 \%$ & clay loam & incorporated & 25 & Rogers et al. 2011 \\
\hline & -0.28 & swine lagoon effluent & FC $80 \%$ & clay loam & incorporated & 25 & Rogers et al. 2011 \\
\hline & -0.33 & cattle manure & FC $60 \%$ & clay loam & incorporated & 25 & Rogers et al. 2011 \\
\hline & -0.37 & cattle manure & FC $80 \%$ & clay loam & incorporated & 25 & Rogers et al. 2011 \\
\hline \multirow[t]{2}{*}{ MS2 phage } & -0.629 & biosolids & $30 \%$ & clay loam & incorporated & 27 & Straub et al. 1992 \\
\hline & -0.652 & biosolids & $30 \%$ & sandy & incorporated & 27 & Straub et al. 1992 \\
\hline \multirow{4}{*}{$\begin{array}{l}\text { S. enterica serovar } \\
\text { Typhimurium/pDs }\end{array}$} & -0.84 & swine lagoon effluent & FC $60 \%$ & clay loam & incorporated & 25 & Rogers et al. 2011 \\
\hline & -0.33 & swine lagoon effluent & FC $80 \%$ & clay loam & incorporated & 25 & Rogers et al. 2011 \\
\hline & -0.81 & cattle manure & FC $60 \%$ & clay loam & incorporated & 25 & Rogers et al. 2011 \\
\hline & -0.76 & cattle manure & FC $80 \%$ & clay loam & incorporated & 25 & Rogers et al. 2011 \\
\hline \multirow[t]{8}{*}{ Salmonella (6 strains) } & -0.0908 & swine lagoon effluent & FC $80 \%$ & sandy & surface & $25-4$ & Holley et al. 2006 \\
\hline & -0.0682 & swine lagoon effluent & FC $80 \%$ & sandy & incorporated & $25-4$ & Holley et al. 2006 \\
\hline & -0.0601 & swine lagoon effluent & FC $80 \%$ & clay loam & surface & $25-4$ & Holley et al. 2006 \\
\hline & -0.0584 & swine lagoon effluent & FC $80 \%$ & clay loam & incorporated & $25-4$ & Holley et al. 2006 \\
\hline & -0.1373 & swine lagoon effluent & FC $60 \%$ & sandy & surface & $25-4$ & Holley et al. 2006 \\
\hline & -0.1358 & swine lagoon effluent & FC $60 \%$ & sandy & incorporated & $25-4$ & Holley et al. 2006 \\
\hline & -0.1109 & swine lagoon effluent & FC $60 \%$ & clay & surface & $25-4$ & Holley et al. 2006 \\
\hline & -0.1105 & swine lagoon effluent & FC $60 \%$ & clay & incorporated & $25-4$ & Holley et al. 2006 \\
\hline Salmonella Newport & -0.0697 & cattle manure & FC $90 \%$ & sandy silt loam & incorporated & 24 & Toth et al. 2011 \\
\hline
\end{tabular}




\begin{tabular}{|c|c|c|c|c|c|c|c|}
\hline \multirow{4}{*}{$\begin{array}{l}\text { Salmonella spp. } \\
\text { (ttrRSBCA) }\end{array}$} & -0.11 & swine lagoon effluent & FC $60 \%$ & clay loam & incorporated & 25 & Rogers et al. 2011 \\
\hline & -0.072 & swine lagoon effluent & FC $80 \%$ & clay loam & incorporated & 25 & Rogers et al. 2011 \\
\hline & -0.34 & cattle manure & FC $60 \%$ & clay loam & incorporated & 25 & Rogers et al. 2011 \\
\hline & -0.26 & cattle manure & FC $80 \%$ & clay loam & incorporated & 25 & Rogers et al. 2011 \\
\hline
\end{tabular}


Table 2 Quantitative PCR primer sequences associated with each bacterial targets

\begin{tabular}{|c|c|c|c|c|}
\hline Target & Locus & Primer sequence (5' to 3') & Primer size & References \\
\hline \multirow{2}{*}{$\begin{array}{c}\text { Campylobacter } \\
\text { jejuni }\end{array}$} & campF2 & CACGTGCTACAATGGCATAT & \multirow{2}{*}{$109 \mathrm{bp}$} & \multirow{2}{*}{ (Wong et al., 2010) } \\
\hline & campR2 & GGCTTCATGCTCTCGAGTT & & \\
\hline \multirow{2}{*}{$\begin{array}{c}\text { E. coli } \\
\text { O157 }\end{array}$} & $\mathrm{vt} 2(\mathrm{stx} 2)-\mathrm{f}$ & TGTTGGCTGGGTTCGTTAATACGG & \multirow{2}{*}{$121 \mathrm{bp}$} & \multirow{2}{*}{ (Lu et al., 2003) } \\
\hline & $\mathrm{vt} 2(\mathrm{stx} 2)-\mathrm{r}$ & TCCGTTGTCATGGAAACCGTTGTC & & \\
\hline \multirow{2}{*}{$\begin{array}{c}\text { Listeria } \\
\text { monocytogenes }\end{array}$} & hlyQF & CATGGCACCACCAGCATCT & \multirow{2}{*}{$64 \mathrm{bp}$} & \multirow{2}{*}{ (Meng et al., 1997) } \\
\hline & hlyQR & ATCCGCGTGTTTCTTTTCGA & & \\
\hline \multirow{2}{*}{$\begin{array}{c}\text { Salmonella } \\
\text { enterica }\end{array}$} & spaQVicF & GCAATTACAGGAACAGACGCT & \multirow{2}{*}{$100 \mathrm{bp}$} & \multirow{2}{*}{ (Scallan et al., 2011a) } \\
\hline & spaQvicR & CCTGACGCCCGTAAGAGA & & \\
\hline
\end{tabular}


Table 3: Significance ( $p$ values) of main effects and interactions by bacterium in mixed model analysis of inactivation rates, with mean inactivation rates $\left(\log \mathrm{d}^{-1}\right)$ for each variable averaged across all experiments, below the main effect.

\begin{tabular}{|c|c|c|c|c|c|c|c|c|c|}
\hline \multirow[b]{2}{*}{ Effect } & \multicolumn{2}{|c|}{ C. jejuni } & \multirow{2}{*}{$\begin{array}{c}\text { C. perfringens }{ }^{1} \\
\text { Cult-Dep }\end{array}$} & \multicolumn{2}{|c|}{ E. coli 0157} & \multicolumn{2}{|c|}{ L. monocytogenes } & \multicolumn{2}{|c|}{ S. enterica } \\
\hline & Cult-Dep $^{2}$ & Cult-Ind & & Cult-Dep & Cult-Ind & Cult-Dep & Cult-Ind & $\begin{array}{l}\text { Cult- } \\
\text { Dep } \\
\end{array}$ & $\begin{array}{c}\text { Cult- } \\
\text { Ind }\end{array}$ \\
\hline Waste-residual & 0.0439 & $<.0001$ & 0.0012 & $<.0001$ & 0.0001 & $<.0001$ & 0.0259 & $<.0001$ & 0.0059 \\
\hline$\underline{\text { Bio }}^{3}$ & $\underline{-0.6732}$ & $\underline{-0.03444}$ & $\underline{-0.0076}$ & $\underline{-0.0809}$ & $\underline{-0.1008}$ & $\underline{-0.2584}$ & $\underline{-0.0442}$ & $\underline{-0.0757}$ & $\underline{-0.07788}$ \\
\hline$\underline{\text { Cat }}$ & $\underline{-0.6887}$ & $\underline{-0.03844}$ & $\underline{-0.0477}$ & $\underline{-0.196}$ & $\underline{-0.0729}$ & $\underline{-0.1835}$ & $\underline{-0.0389}$ & $\underline{-0.0369}$ & $\underline{-0.0626}$ \\
\hline$\underline{\text { Swi }}$ & $\underline{-0.681}$ & $\underline{-0.02429}$ & $\underline{-0.0059}$ & $\underline{-0.1282}$ & $\underline{-0.0549}$ & $\underline{-0.5321}$ & $\underline{-0.0469}$ & $\underline{-0.1583}$ & $\underline{-0.0651}$ \\
\hline$\underline{\text { PBS }}$ & $\underline{-0.6431}$ & $\underline{-0.02084}$ & $\underline{-0.0084}$ & $\underline{-0.1208}$ & $\underline{-0.0559}$ & $\underline{-0.3837}$ & $\underline{-0.0322}$ & $\underline{-0.1362}$ & $\underline{-0.0481}$ \\
\hline Soil & $<.0001$ & $<.0001$ & 0.0369 & 0.3619 & 0.0006 & $<.0001$ & 0.9493 & 0.0646 & 0.3514 \\
\hline$\underline{\text { San }^{4}}$ & $\underline{-0.6279}$ & $\underline{-0.0226}$ & $\underline{-0.0089}$ & $\underline{-0.149}$ & $\underline{-0.0579}$ & $\underline{-0.5321}$ & $\underline{-0.0407}$ & $\underline{-0.1142}$ & $\underline{-0.0608}$ \\
\hline$\underline{\text { Cla }}$ & $\underline{-0.7152}$ & -0.0364 & $\underline{-0.0259}$ & $\underline{-0.1139}$ & $\underline{-0.0844}$ & $\underline{-0.1298}$ & $\underline{-0.0405}$ & $\underline{-0.0894}$ & $\underline{-0.066}$ \\
\hline Management & 0.7288 & 0.0216 & 0.0045 & $<.0001$ & 0.577 & 0.1773 & $<.0001$ & 0.0049 & $<.0001$ \\
\hline$\underline{\text { Inc }^{5}}$ & $\underline{-0.6695}$ & $\underline{-0.0313}$ & $\underline{-0.0054}$ & $\underline{-0.1823}$ & $\underline{-0.0731}$ & $\underline{-0.3589}$ & $\underline{-0.0321}$ & $\underline{-0.0822}$ & $\underline{-0.0808}$ \\
\hline$\underline{\text { Sur }}$ & $\underline{-0.6735}$ & $\underline{-0.0278}$ & $\underline{-0.0294}$ & $\underline{-0.0806}$ & $\underline{-0.0692}$ & $\underline{-0.32}$ & $\underline{-0.0491}$ & $\underline{-0.1214}$ & $\underline{-0.046}$ \\
\hline Residual*Soil & 0.0003 & 0.0004 & 0.0002 & $<.0001$ & 0.0185 & $<.0001$ & 0.0562 & 0.575 & 0.0012 \\
\hline Residual*Manage & 0.0271 & $<.0001$ & 0.0009 & $<.0001$ & 0.0002 & 0.001 & 0.0427 & 0.0077 & 0.2404 \\
\hline Residual*Soil*Manage & $<.0001$ & $<.0001$ & 0.0003 & $<.0001$ & 0.0027 & 0.0002 & $<.0001$ & 0.194 & 0.5988 \\
\hline
\end{tabular}

TqPCR was not performed for $C$. perfringens detection.

${ }^{2}$ Cult-Dep = cultivation-dependent; Cult-Ind = cultivation independent

${ }^{3}$ Mean inactivaton, k-rates, $\left(\log \mathrm{d}^{-1}\right)$. Bio = biosolids, Cat = cattle manure, Swi = swine effluent, and PBS = PBS control.

${ }^{4}$ Mean inactivaton, k-rates, $\left(\log \mathrm{d}^{-1}\right)$. San = sandy loam soil, $\mathrm{Cla}=$ clay loam soil.

${ }^{5}$ Mean inactivaton, k-rates, $\left(\log \mathrm{d}^{-1}\right)$. Inc $=$ incorporated, Sur $=$ surface-applied. 
Table 4: Inactivation rates (k-rates) derived via cultivation-dependent and -independent methods

\begin{tabular}{|c|c|c|c|c|c|c|c|c|c|c|c|c|c|c|}
\hline & \multicolumn{14}{|c|}{ Decay Rates $\left(\log _{10}\left(N_{t} / N_{0}\right) / t\right)$} \\
\hline \multirow{2}{*}{$\begin{array}{c}\text { Soil Type } \\
\text { and } \\
\text { Management } \\
\text { Practice } \\
\end{array}$} & $\begin{array}{l}\text { Residual } \\
\text { Applied }\end{array}$ & \multicolumn{2}{|c|}{ C. jejuni ${ }^{1}$} & \multicolumn{2}{|c|}{ C. perfringens } & \multicolumn{2}{|c|}{ E. coli $0157^{1}$} & \multicolumn{2}{|c|}{ L. monocytogenes ${ }^{1}$} & S. enterica ${ }^{1}$ & \multicolumn{2}{|c|}{ MS2 phage ${ }^{1}$} & \multicolumn{2}{|c|}{$\varnothing \times 174$ phage $^{1}$} \\
\hline & & Cult-Dep $^{12}$ & Cult-Ind & Cult-Dep & Cult-Ind & Cult-Dep & Cult-Ind & Cult-Dep & Cult-Ind & Cult-Dep Cult-Ind & Cult-Dep & $\begin{array}{l}\text { Cult- } \\
\text { Ind }\end{array}$ & Cult-Dep & $\begin{array}{l}\text { Cult- } \\
\text { Ind }\end{array}$ \\
\hline \multicolumn{15}{|l|}{ Sandy loam } \\
\hline \multirow[t]{4}{*}{$\begin{array}{l}\text { Surface- } \\
\text { applied }\end{array}$} & Biosolids & $-0.5857^{2}$ & $-0.0287^{6}$ & $-0.0245^{8}$ & ND & $\underline{-0.1261^{5}}$ & $-0.1512^{5}$ & $-0.2522^{5}$ & $-0.0459^{6}$ & $\underline{-0.0760^{6}}-0.0767^{5}$ & $-0.0827^{6}$ & ND & $-0.1219^{5}$ & ND \\
\hline & Cattle & $-0.5666^{2}$ & $-0.0153^{6}$ & $-0.0046^{10}$ & ND & $\underline{-0.0216^{10}}$ & $-0.026^{6}$ & $-0.4188^{3}$ & $-0.035^{6}$ & $\underline{-0.0225^{11}}-0.026^{6}$ & $-0.2116^{4}$ & ND & $-0.0709^{6}$ & ND \\
\hline & Swine & $-0.6032^{2}$ & $-0.004^{6}$ & $-0.009^{11}$ & ND & $-0.2266^{4}$ & $-0.0311^{6}$ & $-1.049^{2}$ & $-0.0362^{6}$ & $-0.1941^{5}-0.0311^{6}$ & $-0.1803^{3}$ & ND & $-0.1381^{3}$ & ND \\
\hline & PBS & $-0.5329^{2}$ & $-0.0001^{6}$ & $-0.0121^{9}$ & ND & $-0.1737^{3}$ & $-0.0371^{6}$ & $-0.4949^{3}$ & $-0.0472^{6}$ & $-0.1855^{5}-0.0371^{6}$ & $-0.15^{3}$ & ND & $-0.2829^{3}$ & ND \\
\hline \multirow[t]{4}{*}{ Incorporated } & Biosolids & $-0.6525^{2}$ & $-0.0299^{6}$ & $-0.0012^{8}$ & ND & $-0.1148^{5}$ & $-0.0605^{5}$ & $-0.4859^{3}$ & $-0.0278^{6}$ & $\underline{-0.0968^{5}}-0.1115^{5}$ & $-0.0629^{6}$ & ND & $-0.262^{4}$ & ND \\
\hline & Cattle & $-0.6758^{2}$ & $-0.0354^{6}$ & $-0.0036^{11}$ & ND & $-0.0544^{7}$ & $-0.08^{5}$ & $-0.0641^{7}$ & $-0.0537^{6}$ & $-0.0475^{8}-0.0829^{5}$ & $-0.2638^{4}$ & ND & $-0.0719^{5}$ & ND \\
\hline & Swine & $-0.7696^{2}$ & $-0.0338^{6}$ & $-0.0089^{11}$ & ND & $\underline{-0.24^{4}}$ & $-0.0256^{5}$ & $-0.8402^{2}$ & $-0.055^{6}$ & $-0.161^{3}-0.0644^{5}$ & $-0.0982^{4}$ & ND & $-0.1806^{5}$ & ND \\
\hline & PBS & $-0.6365^{2}$ & $-0.0033^{6}$ & $-0.0075^{11}$ & ND & $-0.2471^{4}$ & $-0.0511^{5}$ & $-0.7872^{2}$ & $-0.0248^{6}$ & $-0.1302^{5}-0.0567^{5}$ & $-0.182^{3}$ & ND & $-0.6566^{2}$ & ND \\
\hline \multicolumn{15}{|l|}{ Clay loam } \\
\hline \multirow[t]{4}{*}{$\begin{array}{l}\text { Surface- } \\
\text { applied }\end{array}$} & Biosolids & $-0.802^{2}$ & $-0.0600^{6}$ & $-0.0045^{11}$ & ND & $\underline{-0.026^{7}}$ & $-0.1^{5}$ & $-0.1157^{5}$ & $-0.0698^{6}$ & $-0.0655^{7}-0.0488^{5}$ & $-0.1029^{4}$ & ND & $-0.1617^{4}$ & ND \\
\hline & Cattle & $-0.8352^{2}$ & $-0.0359^{6}$ & $-0.1758^{3}$ & ND & $\underline{-0.0308^{7}}$ & $-0.0997^{5}$ & $-0.0814^{5}$ & $-0.0427^{6}$ & $\underline{-0.0422^{8}}-0.0456^{6}$ & $-0.8324^{2}$ & ND & $-0.218^{3}$ & ND \\
\hline & Swine & $-0.7656^{2}$ & $-0.0407^{6}$ & $0.0053^{11}$ & ND & $-0.0278^{7}$ & $-0.08^{5}$ & $\underline{-0.0518^{5}}$ & $-0.0812^{5}$ & $-0.2079^{5}-0.0767^{5}$ & $-0.4512^{2}$ & ND & $-0.1039^{4}$ & ND \\
\hline & PBS & $-0.6967^{2}$ & $-0.0371^{6}$ & $-0.01^{3}$ & ND & $\underline{-0.0237^{7}}$ & $-0.0282^{5}$ & $-0.0958^{5}$ & $-0.0345^{5}$ & $-0.1775^{5}-0.026^{5}$ & $-0.199^{3}$ & ND & $-0.038^{6}$ & ND \\
\hline \multirow[t]{4}{*}{ Incorporated } & Biosolids & $-0.6525^{2}$ & $-0.0191^{3}$ & $-0.0003^{11}$ & ND & $-0.0568^{7}$ & $-0.0918^{5}$ & $-0.1798^{5}$ & $-0.0334^{6}$ & $-0.0648^{7}-0.0705^{5}$ & $-0.1089^{5}$ & ND & $-0.1954^{4}$ & ND \\
\hline & Cattle & $-0.6772^{2}$ & $-0.0671^{5}$ & $-0.007^{11}$ & ND & $-0.6772^{7}$ & $-0.0861^{5}$ & $-0.1698^{5}$ & $-0.0242^{6}$ & $\underline{-0.0354^{9}}-0.0957^{5}$ & $-0.6691^{2}$ & ND & $-0.1925^{4}$ & $\mathrm{ND}$ \\
\hline & Swine & $-0.5856^{2}$ & $-0.0186^{6}$ & $-0.011^{11}$ & ND & $\underline{-0.0304^{7}}$ & $-0.0823^{5}$ & $-0.1873^{5}$ & $-0.0154^{6}$ & $\underline{-0.0702^{7}}-0.0881^{5}$ & $-0.5472^{2}$ & $\mathrm{ND}$ & $-0.1326^{4}$ & ND \\
\hline & PBS & $-0.7064^{2}$ & $-0.0130^{6}$ & $-0.0041^{11}$ & ND & $\underline{-0.0385^{7}}$ & $-0.1069^{5}$ & $-0.157^{5}$ & $-0.0022^{6}$ & $\underline{-0.0515^{8}}-0.0725^{5}$ & $-0.5107^{2}$ & ND & $-0.0507^{6}$ & ND \\
\hline
\end{tabular}

${ }^{1}$ Inactivation rates derived by cultural (left) and qPCR (right) methods using CFU or GU g ${ }^{-1}$ data from 0 to final time point with detection limits, unless specified. The underlined rates are cultivated data which indicate bacterial inactivation rates that are slower than comparable cultivationindependent rates. ${ }^{2}$ Detection limits reached at day $7 ;{ }^{3}$ at day $14 ;{ }^{4}$ at day $21 ;{ }^{5}$ at day $28 ;{ }^{6}$ at day $60 ;{ }^{7}$ at day $90 ;{ }^{8}$ at day $120 ;{ }^{9}$ at day $150 ;{ }^{10}$ at day $180 ;{ }^{11}$ at day $210 .{ }^{12}$ Cult-Dep = cultivation-dependent; Cult-Ind = cultivation independent 
Table 5 Ratio of cultivation-dependent $\left(\mathrm{CFU} \mathrm{g}{ }^{-1}\right)$ to -independent $\left(\mathrm{GU} \mathrm{g}^{-1}\right)$ for E. coli O157, L. monocytogenes, and S. enterica

\begin{tabular}{|c|c|c|c|c|c|c|c|c|c|c|c|c|c|}
\hline \multirow{2}{*}{$\begin{array}{c}\text { Soil Type } \\
\text { and } \\
\text { Management } \\
\text { Practice }\end{array}$} & \multirow{2}{*}{$\begin{array}{c}\text { Residual } \\
\text { Applied }\end{array}$} & \multicolumn{4}{|c|}{ E. coli 0157} & \multicolumn{4}{|c|}{ L. monocytogenes } & \multicolumn{4}{|c|}{ S. enterica } \\
\hline & & $\mathbf{0}$ & 7 & 14 & 30 & $\mathbf{0}$ & 7 & 14 & 30 & $\mathbf{0}$ & 7 & 14 & 30 \\
\hline \multirow{5}{*}{$\begin{array}{c}\text { Sandy loam } \\
\text { Surface- } \\
\text { applied }\end{array}$} & & & & & & & & & & & & & \\
\hline & Biosolids & 1.4407 & 1.5446 & 1.3239 & 0.6439 & 1.5471 & 0.6202 & 0.9200 & $<0.0001$ & 0.8486 & 1.0162 & 0.7372 & 0.6866 \\
\hline & Swine & 1.5980 & 1.4276 & 1.3353 & $<0.0001$ & 1.7949 & $<0.0001$ & $<0.0001$ & $<0.0001$ & 0.9484 & 1.1092 & 1.0678 & 0.4801 \\
\hline & Cattle & 1.4167 & 1.1838 & 1.4241 & 1.6726 & 1.7774 & 0.8967 & 0.4450 & $<0.0001$ & 0.8284 & 0.9896 & 1.1599 & 1.1078 \\
\hline & PBS & 1.6437 & 1.4395 & 1.1197 & $<0.0001$ & 1.5563 & 1.0589 & 0.0000 & $<0.0001$ & 0.9809 & 1.1438 & 0.9900 & 0.5394 \\
\hline \multirow[t]{4}{*}{ Incorporated } & Biosolids & 1.2140 & 1.1558 & 0.7111 & 0.8577 & 2.2659 & 0.4214 & 0.1981 & $<0.0001$ & 0.7563 & 0.9206 & 0.5677 & 0.6732 \\
\hline & Swine & 1.0828 & 0.9680 & 0.6769 & $<0.0001$ & 1.4914 & 0.3533 & $<0.0001$ & $<0.0001$ & 0.6662 & 0.9210 & 0.3901 & 0.0000 \\
\hline & Cattle & 1.0474 & 1.2504 & 1.2432 & 1.4079 & 1.8213 & 1.7863 & 1.7615 & 1.3683 & 0.8798 & 1.1260 & 1.2487 & 1.2509 \\
\hline & PBS & 1.1013 & 0.6739 & 0.3199 & $<0.0001$ & 1.6433 & 0.4491 & $<0.0001$ & $<0.0001$ & 0.8382 & 0.6440 & 0.4435 & 0.3064 \\
\hline \multirow{5}{*}{$\begin{array}{l}\text { Clay loam } \\
\text { Surface- } \\
\text { applied }\end{array}$} & & & & & & & & & & & & & \\
\hline & Biosolids & 1.2341 & 0.9652 & 0.9497 & 1.6771 & 1.0447 & 1.0308 & 0.8346 & 0.5545 & 1.0403 & 0.6179 & 0.6161 & 0.1387 \\
\hline & Swine & 1.2807 & 1.4663 & 1.5907 & 1.4384 & 0.9409 & 1.0146 & 1.1931 & 1.2475 & 1.0955 & 0.8512 & 0.1721 & 0.2160 \\
\hline & Cattle & 1.2730 & 1.9237 & 2.0552 & 1.7867 & 1.0720 & 1.7420 & 1.0140 & 1.1671 & 1.1235 & 1.1931 & 1.2030 & 0.7032 \\
\hline & PBS & 1.5719 & 1.3347 & 1.5460 & 1.5120 & 1.5076 & 1.2688 & 1.1566 & 0.8399 & 1.2655 & 1.0730 & 0.9339 & 1.6117 \\
\hline \multirow[t]{4}{*}{ Incorporated } & Biosolids & 1.3251 & 1.1261 & 0.9621 & 1.5435 & 2.4406 & 0.6484 & 0.6392 & 7.8575 & 0.9544 & 1.0246 & 0.8106 & 0.6442 \\
\hline & Swine & 1.2846 & 1.2166 & 1.3751 & 1.6713 & 2.6752 & 1.0846 & 0.7920 & 1.0122 & 1.3074 & 1.0977 & 0.9926 & 1.0407 \\
\hline & Cattle & 1.2186 & 1.2495 & 1.8742 & 1.5457 & 2.4286 & 1.5004 & 1.5115 & 2.7298 & 1.3351 & 1.1790 & 1.3902 & 2.2471 \\
\hline & PBS & 1.0817 & 1.1264 & 1.1740 & 1.2051 & 2.4230 & 1.3857 & 1.0989 & 1.6692 & 1.0466 & 1.2237 & 1.1336 & 0.7830 \\
\hline
\end{tabular}

No shading = ratios of cultivation-dependent: -independent are within $1.0 \pm 0.25$ limits. Dark gray shading indicates cultivation data provided higher bacterial counts than cultivation-independent detection. Light gray shading indicates cultivation-independent data provided higher bacterial counts than cultivation. 


\section{Pathogen Decay in Microcosms Representing Land Application}
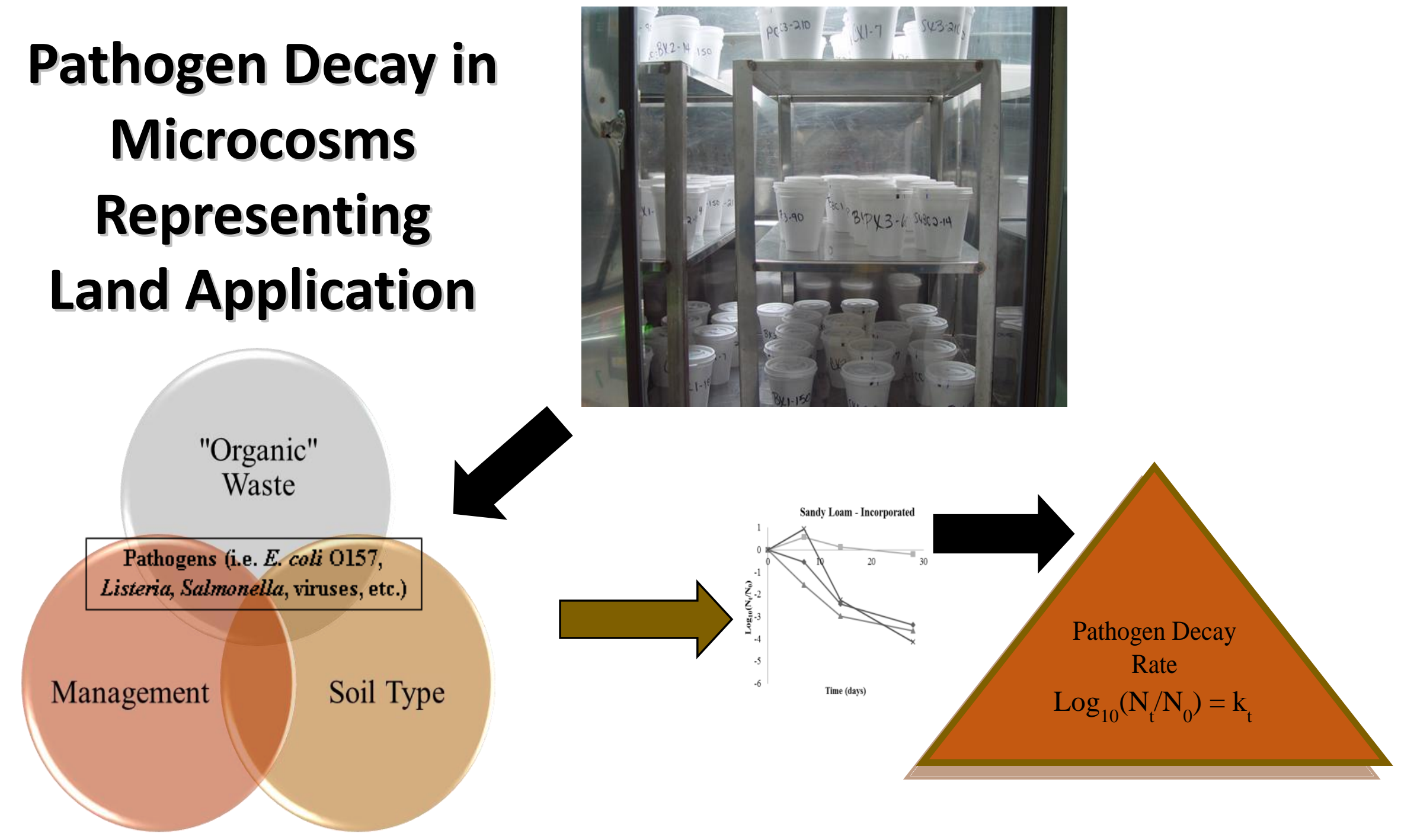

Land application of "Organic" Wastes: Class B biosolids, Swine effluent, \& Cattle manure 